\title{
Non-Tariff Measures: A global context for the changing international competitiveness of the Canadian softwood lumber industry
}

\author{
by David H. Cohen ${ }^{1}$, Nobuyuki Muto² and Robert A. Kozak ${ }^{3}$
}

The Canadian softwood lumber industry is currently at a critical juncture in its development. Despite a global trend towards liberalized trade and the removal of trade restrictions, exporters of softwood lumber-one of Canada's most important economic sectorsfind themselves embroiled in a contentious trade dispute once again. This paper has the overarching aim of stepping back from the details of current trade issues to provide a global context for protectionist actions, particularly Non-Tariff Measures (NTMs). Specifically, it draws parallels from the evolution of NTMs in the agricultural sector and provides an overview of some of the factors which lead to the implementation of NTMs in the lumber sector, including oversupply, process innovation, product innovation and recession. Based on this review, the paper offers a possible framework for the early detection of triggers that indicate the likelihood of importing regions sanctioning protectionist actions like NTMs. While this framework is only a starting point in mitigating the threat of protectionist trade measures, ultimately tools like this should be employed to maintain the long-term competitiveness of the Canadian softwood industry.

Key words: Non-Tariff Measures (NTMs), trade, exports, softwood lumber, competitiveness, oversupply, process innovation, product innovation, technology, recession

L'industrie canadienne du bois de sciage de résineux est présentement à un point crucial de son développement. Malgré une tendance mondiale vers la libéralisation des marchés et le retrait des barrières commerciales, les exportateurs de bois de sciage de résineux - l'un des secteurs économiques les plus importants au Canada - sont entraînés à nouveau dans un conflit commercial. Cet article cherche avant toute chose à prendre un certain recul face aux détails des enjeux commerciaux actuels afin d'élaborer un contexte global des mesures protectionnistes, en particulier les Mesures non-tarifaires (MNT). De façon spécifique, cet article élabore un parallèle de l'évolution des MNT dans le secteur agricole et présente un survol de certains de ces facteurs qui ont mené à l'implantation des MNT dans le secteur du bois de sciage et qui comprend les surplus de production, les innovations dans les processus, les innovations au niveau des produits et les récessions. En fonction de cette revue, l'article présente un cadre de travail potentiel pour la détection hâtive des déclencheurs qui indiquent la possibilité de la part des régions importatrices de la mise en place de mesures compensatoires de protection comme les MNT. Même si ce cadre de travail n'est que le point de départ de la mitigation de la menace de mesures de protection commerciale, en fin de compte, de tels outils devraient être employés pour maintenir la compétitivité à long terme de l'industrie canadienne du bois de sciage de résineux.

Mots-clés: Mesures non tarifaires, échanges commerciaux, exportations, bois de sciage de résineux, compétitivité, surplus, innovation des processus, innovation des produits, technologie, récession

\section{Introduction}

In the wake of the expiration of the Canada-US Softwood Lumber Agreement and the subsequent ratification of countervailing and anti-dumping duties by the United States in May 2002, it remains to be seen how the Canadian softwood lumber industry will fare. What is known is that our collective strategy against protectionist actions can best be described as reactive and not

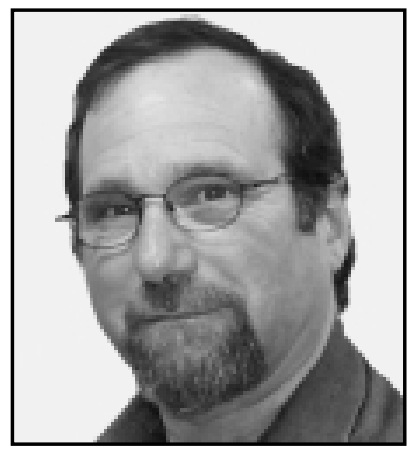

David H. Cohen very effective. As one of the world's leading exporters of wood products and softwood lumber, we should be taking a proac-

\footnotetext{
${ }^{1}$ Associate Professor, Faculty of Forestry, University of British Columbia, 4041 - 2424 Main Mall, Vancouver, B.C. V6T 1Z4. E-mail: dcohen@ interchange.ubc.ca

${ }^{2}$ Chief of Liaison, Research and Extension Division, Japanese Forestry Agency, Ministry of Agriculture, Forestry and Fisheries, 1-2-1 Kasumigaseki,, Chiyoda-ku, Tokyo 100-8952, Japan. E-mail: nobuyuki_muto@ nm.maff.go.jp

${ }^{3}$ Associate Professor, Faculty of Forestry, University of British Columbia, 4041 - 2424 Main Mall, Vancouver, B.C. V6T 1Z4 E-mail: rkozak@ interchange.ubc.ca
}

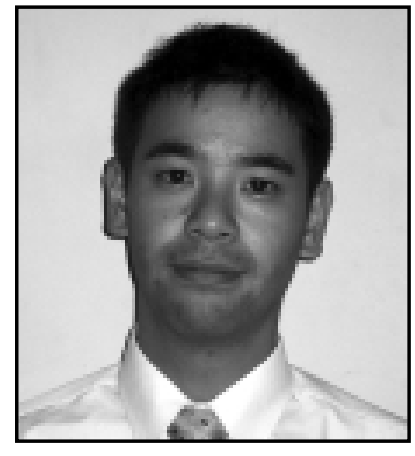

Nobuyuki Muto

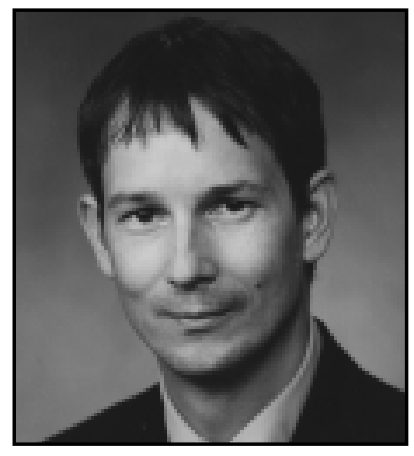

Robert A. Kozak tive stance against the implementation of protectionist actions by importing nations, particularly in the case of Non-Tariff Measures (NTMs).

The situation for softwood lumber is not an isolated incident and lessons can be learned by looking to the use of NTMs in a broader context, both in terms of other industries such as agriculture and within a global perspective. Understanding some of the triggers that catalyze protectionism may better prepare the Canadian wood products industry against future unilateral actions. The objective of this paper is to describe the underlying fundamentals that have propelled, and will continue to propel, increasing protectionism in the wood products sector 
by major economic regions such as Europe and the United States. This paper examines restrictive trade actions that have hurt the Canadian softwood lumber industry and provides a global context for its changing international competitiveness. In so doing, a framework is presented which serves to identify some of the key triggers that lead to the implementation of NTMs.

Despite the global trend towards increased free trade using both bilateral (e.g., the North American Free Trade Agreement) and multilateral negotiations (e.g., the World Trade Organization), some sectors have been successful in implementing trade restrictions. Examples include softwood lumber producers and the steel industry in the US, magazine publishers in Canada and the agricultural sector in Europe. The two most preferred methods of restricting free trade are industry subsidies (in the case of agriculture) and the use of NTMs that can be implemented without contravening most trade agreements.

NTMs are classified into three categories: 1) Social/Political; 2) Health and Safety; and 3) Environmental. The objective of Social/Political measures, which include surcharges, import and export taxes, and license requirements, is to maintain or increase the size of the domestic industry and protect domestic employment. The Canada-US Softwood Lumber Agreement (SLA) was an example of this type of measure. Health and Safety measures, which include phytosanitary and health standards, have at times been used as vehicles to protect domestic industries from foreign competition. It can be argued that the European ban on unseasoned softwood lumber imports is as an example of this type of measure (Eastin and Fukuda 2001). Environmental NTMs are any measures that restrict market access by imposing minimum environmental standards to protect domestic industries from global competition. These are becoming increasingly popular tools for Environmental Non-Governmental Organizations (ENGOs) (New Zealand Forest Research Institute 1999).

There has been increased use of NTMs to restrict trade since the 1980s (New Zealand Forest Research Institute 1999). The Canadian softwood lumber industry has been (and continues to be) export-oriented and is highly susceptible to any form of increased trade restrictions. Eastin and Fukuda (2001) presented a series of NTMs and changing regulations in Europe, the United States (US), and Japan during the 1990s, which contributed to a decline in Canadian international competitiveness (Eastin and Fukuda 2001).

This paper first summarizes the evolution of increasing protectionism for agricultural products with a focus on how this pattern is being repeated in the manufacturing sector. This is followed by a discussion of recent measures restricting free trade in softwood lumber to Europe and the US. A framework for increasing restrictions on free trade is presented, focussing the importance of technology within this framework. Finally, a discussion on how the Canadian industry can (continue to) be proactive in meeting these challenges to international competitiveness is offered.

\section{Protectionism in Agriculture}

The adoption of new technologies that serve to improve product quality, productivity, or production often leads to lower prices for consumers. Improvements in technology are cyclical and can lead to reductions in employment. This technology driven improvement contributes to a climate that promotes protectionism to "save" jobs (Grübler 1998). According to Grübler (1998), this cycle occurred in the resource-intensive sectors - dominated by agriculture and to a lesser extent mining - during the twentieth century. Despite a decline in the agricultural population (i.e., the number of people deriving their living from agricultural activities) in developed countries for the past 40 years, agricultural production has not decreased. For example, the overall agricultural population needed to produce wheat has declined by a factor of three since 1950, but production has almost doubled (Fig. 1). This trend is most prevalent in developed countries where the higher cost of labour encourages the adoption of technology. Technologies, such as intensive farming methods, improved herbicides and pest control, and biotechnology, have increased yields and overall production, while decreasing the unit cost of production. However, this efficiency improvement has led to oversupply, which in turn has led to excessive price reductions. Subsidies were introduced as a means of ensuring that the agricultural sector could recover its investment in technology and be protected against revenue reductions. Today, farmers in the EU receive $35 \%$ of their income from subsidies and those in the US receive $21 \%$, which is projected to increase by $80 \%$ in the next decade (Economist 2002a,b).

As the economic importance of agriculture declined, the industrial sector was expanding and manufacturing became the driving economic force for both job creation and economic activity. Grübler (1998) and Doyle (2002) indicate that this cycle is being repeated today with the same pattern of technology development leading to oversupply and lower prices in manufacturing, increasing protection for many manufacturing sectors and a corresponding increase in the importance of the service sector both in job creation and in generating economic activity. Today, the role of manufacturing can be likened to agriculture in the past, as the service sector becomes the engine of economic growth and employment.

Protectionism often wears the robes of retaliation, with many actions being predicated on the assumption that there has been a transfer of jobs from one region to another due to lower labour costs or subsidies. However, recent studies by Rowthorn and Ramaswamy (1998) show that only $20 \%$ of manufacturing job losses are due to shifts of manufacturing facilities to regions with lower production costs. The remaining job losses $(80 \%)$ are attributed to increased productivity, oftentimes due to the adoption of more efficient technologies.

Currently, many of the aforementioned global trends are also occurring in the wood products industry. Specifically, there have been a series of national reactions to develop and support protectionist movements, predominantly using NTMs to circumvent current international and bilateral trade agreements. These are explored in further detail in the following section using the timely example of softwood lumber.

\section{NTMs for Softwood Lumber}

Technological adaptations have contributed to an oversupply situation for solid wood products that has triggered increased protectionist measures in both the US and Europe. The softwood lumber sectors in these regions have moved towards the use of NTMs to protect their domestic markets for their domestic producers (Eastin and Fukada 2001).

Drucker (2001) indicated that protectionism could occur as a result of nostalgia and political movements. This may be the case for solid wood products. The increasing market share of lower-cost Canadian softwood lumber in the US triggered a polit- 


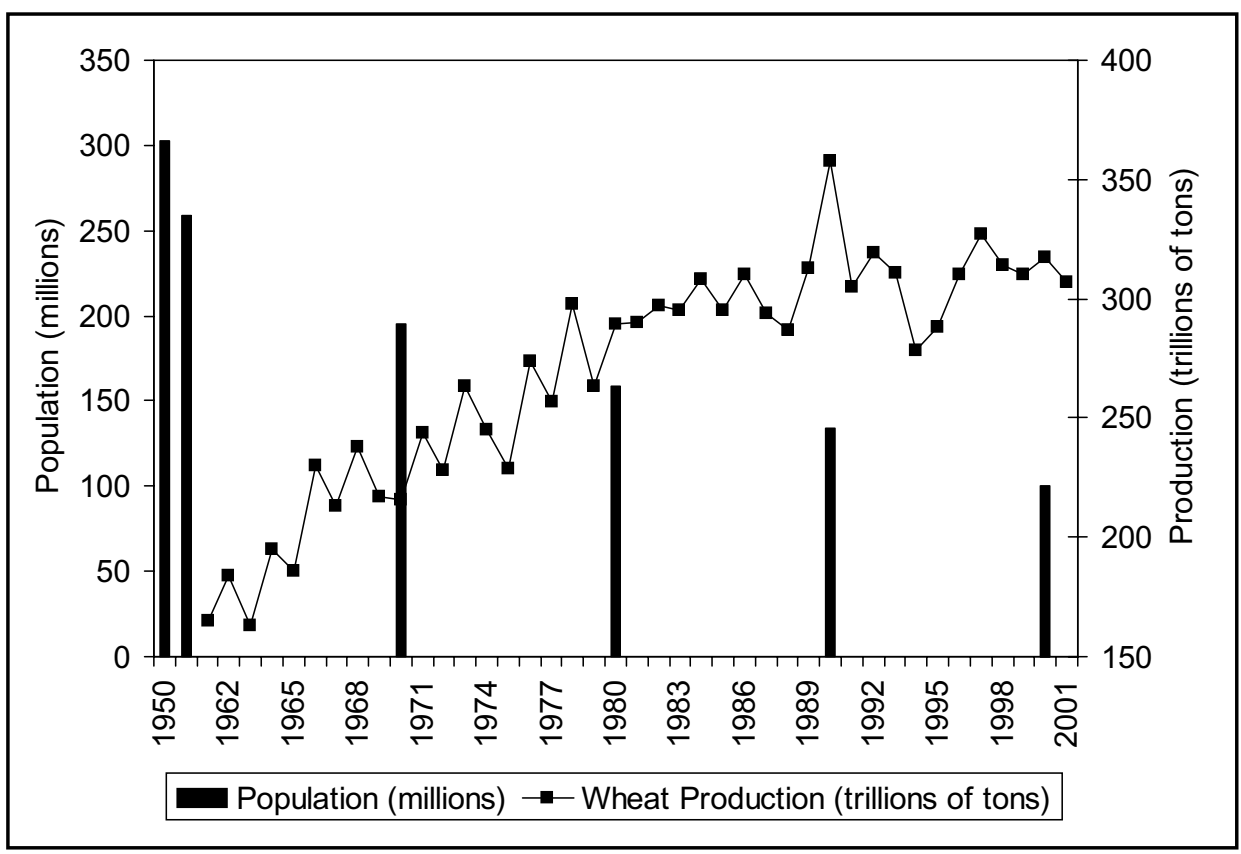

Fig. 1. Agricultural Population and Wheat Production in Developed Countries from 1950 to 2001 (Source: FAO 2001). ical movement promoting US protectionism, represented by the Canada-US Softwood Lumber Agreement (Apsey and Thomas 1997). While some US sawmills are currently upgrading their facilities to retain their market share and adopt new technologies in order to compete, they also seek NTMs to ensure adequate prices to recover their investment costs (McKenna 2001). Nostalgia plays an important role in these actions. Just as protection of the family farm has triggered massive subsidies to large-scale industrialized agricultural enterprises in the US, efforts to protect the small family sawmill have catalyzed significant financial rewards for large industrial wood products firms and particularly institutional owners of large tracts of private forest lands (the benefits to the very large forest land owners in the US are noted in CIBC World Markets (2002)).

Since 1990, Europe has banned unseasoned softwood lumber imports from certain countries outside of Europe. This regulation has been considered a non-tariff measure (NTM) by exporting countries that are targeted by the ban since it effectively works as an obstacle to softwood lumber exports to European countries. The import ban removed Canadian competition from what had been one of its most important export markets, the United Kingdom (Eastin and Fukuda 2001). These restrictions created additional market opportunities for increased production of Scandinavian and other European softwood lumber producers, brought along largely by their adoption of new technologies that increased productivity and overall production volumes.

\section{Phytosanitary measures by the European Union}

In 1983, Finland announced that the pinewood nematode had been discovered in wood chips from North America (TED 1993). The pinewood nematode (Bursaphelenchus xylophilus) is a microscopic roundworm that is vectored from tree to tree by pine sawyer beetles and is endemic to the United States, Canada, Mexico, Japan, China, Taiwan, and Korea. Once the nematode infects pine trees, the tree loses its vitality and wilts (TED 1993).

The regulation was implemented during a recession in United Kingdom, the largest importer of softwood lumber in
Europe. In 1990, the European Community (EC), along with the countries that formed part of the European Free Trade Area (EFTA), announced that a ban on green softwood lumber (except for western red cedar) imports to all European countries from the US, Canada, China and Japan would be implemented in 1993 (Eastin and Fukuda 2001, Hicks 2001). Before the ban came into effect in 1993, the interim regulation (1990 to 1993) required that certain treatments be completed as a precaution against transporting the pinewood nematode to Europe (Eastin and Fukuda 2001, Hicks 2001). Softwood lumber had to meet one of the following criteria:

- kiln-dried to a moisture content below $20 \%$; or

- heat-treated to a core temperature of $56^{\circ} \mathrm{C}$ for at least thirty minutes; or

- accompanied by a "Certificate of Debarking and Grub Hole Control."

After implementation of the ban in October 1993, all lumber from the United States, Canada, Mexico, Japan, China, Taiwan, and Korea was required to be heat-treated or kiln-dried and accompanied by a phytosanitary certificate issued by a government agency (Eastin and Fukuda 2001).

The complexity and severity of these health and safety requirements, and the manner in which they were enforced, had a substantial effect on trade. As a result, they are regarded as NTMs by exporting countries. The primary complaints against such NTMs are that the regulations and their administration are excessively restrictive, going well beyond the level necessary to ensure adequate protection (Bourke and Leitch 1998). Interestingly, Finnish lumber produced from imported Russian logs as well as larger dimension western hemlock and Douglas fir timber imported to the UK were exempt from these measures. This latter point provides additional arguments that identify this situation as a NTM and not a phytosanitary issue since the nematode makes no distinction based on the size of lumber (Random Lengths 1993, Eastin and Fukuda 2001).

To evaluate the impact of this NTM on European producers, the case of Sweden, Europe's largest softwood lumber exporter, 


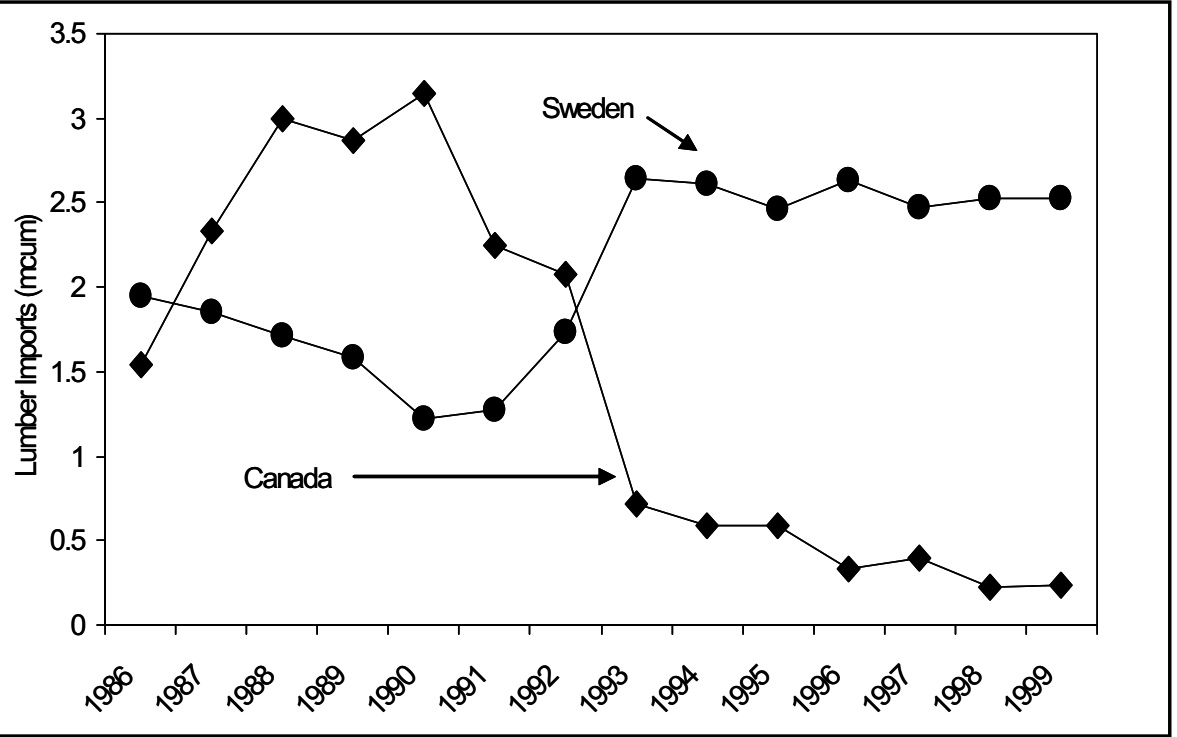

Fig. 2. Sweden and Canada Softwood Lumber Exports to Europe (Source: Taylor 1999). is explored. In 2000 , Sweden exported $75 \%$ or 11.2 million cubic meters (mcum) of its softwood lumber production, with more than half its exports destined for European markets (Taylor 1999, FAO 2001). The effect of the European restriction on softwood lumber exports was clear. Swedish exports to the UK (Europe's largest softwood lumber importer) had been decreasing from 1986 until 1990 when the ban was first announced (Taylor 1999). Canadian softwood lumber exports to the UK had been increasing since 1986, capturing market share from European producers From 1986 to 1990, the volume of exports from Canada to the UK more than doubled from 1.5 mcum to 3.2 mcum. After the ban in 1990, the volume of softwood lumber from Canada decreased substantially to less than 0.7 mcum in 1993 (Fig. 2). Since the ban was announced and enacted, Sweden has not only regained the market share that it had previously lost to Canada, but the UK has become an increasingly important market for larger volumes of Swedish softwood lumber exports. In fact, the UK is the largest importer of Swedish softwood lumber with $24 \%$ of all Swedish softwood lumber in 1999 being shipped there (Taylor 1999). During the 1990s, the structure of Swedish softwood lumber industry changed dramatically and it can be argued that the increased productivity from these technologydriven changes was one of the major drivers to support the Nematode trade restriction.

Part of this restructuring was an increase in the productivity and efficiency of Swedish sawmills. Although more than two thousand sawmills were operating in Sweden in 2000, most of them were small (Skogsindustrierna 2001). According to a survey conducted among sawmills that produced over 5000 cubic meters (cum) per year (Nylinder et al. 1997), the number of sawmills in Sweden has been decreasing for several decades (Fig. 3). The largest reduction was in small sawmills that produced less than 25000 cum annually. Despite a decline in the number of sawmills in Sweden between 1990 and 1995, the number of larger sawmills (i.e., those that produced between 50 and 100 thousand cum) increased, as did the production per sawmill (Fig. 4). These changes were due largely to the rapid restructuring and sizeable capital spending on technological improvements during the 1990s (Swedish Institute 2001).
Like the technological evolution of the agricultural sector, a consolidation of ownership also took place in the Swedish sawmilling sector, along with increases in firm sizes and productivity. As a result of this consolidation, the twenty largest companies accounted for $65 \%$ of total Swedish softwood lumber production in 2000 (Skogsindustrierna 2001). Swedish production of softwood lumber has increased by $26 \%$ from 11.8 million cubic meters (mcum) in 1990 to 14.8 mcum in 2000, despite the decline in the overall number of sawmills (Fig. 5; FAO 2001). Much of this increased production was a direct result of the adoption of new technologies. For example, the adoption of new sawmilling technology allowed for the inclusion of small diameter logs, with a top end diameter of less than $14 \mathrm{~cm}$, to be used as saw logs. This additional volume now accounts for $8 \%$ of the total volume of logs consumed in sawmills (Nylinder et al. 1997). In addition, worker productivity increased dramatically with the annual production of lumber per worker doubling in the past twenty years to approximately 1100 cubic meters in 1995 (Nylinder et al. 1997). This is a direct result of continuous efforts to modernize through automation between 1990 and 1995 (Nylinder et al. 1997).

Basic product life cycle theory suggests that once markets and products have matured, the industry seeks more efficient processing by adopting technologies to lower costs or to reduce the work force (McCarthy et al. 1986). This corresponds to the "process innovation" stage in technology development (Hill and Utterback 1979). Swedish production of softwood lumber increased after the initial implementation of the pinewood nematode ban in 1990 due to improvements in the productivity of Swedish sawmills through process innovation. For the successful adoption of these process innovations, it was important that new markets were available to absorb some of this increased production without precipitating a price decrease as a result of oversupply. Both Sweden and Finland, members of EFTA, were strong supporters of the European ban on green softwood lumber from North America. This had the net effect of creating room in the European market for this increased production volume, catalyzing the necessary structural changes in the Swedish (and other European) sawmill sector to meet this increased demand. 

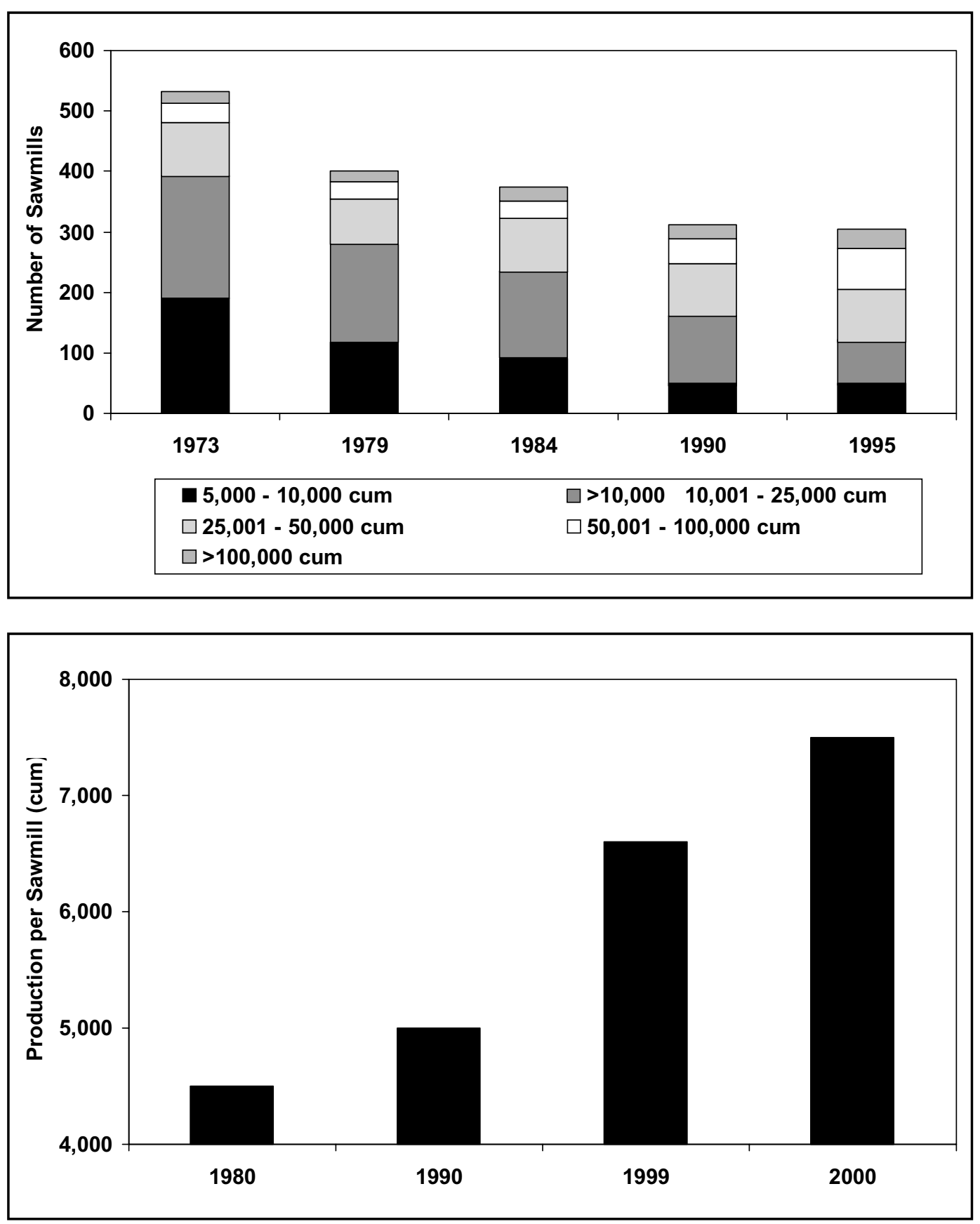

Fig. 3. The Number of Swedish Sawmills by Production Size (Source: Nylinder et al. 1997).
Fig. 4. Average Productivity of Swedish Sawmills (Source: Skogsindustrierna 2001).

\section{The SLA application by the United States}

The Canada-US Softwood Lumber Agreement (SLA) is one example of a social/political NTM for wood products. The SLA worked to limit Canadian softwood lumber exports to the US from 1996 to 2001 (Eastin and Fukuda 2001). Between 1982 and 1996, the US industry petitioned three times for a countervailing duty to protect domestic markets for domestic producers of softwood lumber. This section presents a brief chronology of events to provide background on the persistence of the US industry to use NTMs for protection from Canadian lumber imports.

In 1979, the US economy entered an economic recession, combined with a period of higher interest rates and inflation due to government fiscal and monetary policies (Fukuda 2001). The recession included a decline in housing starts, the primary driver of softwood lumber demand in the US, and a corresponding decline in lumber demand from 1978 to 1982 (Fig. 6).

The first modern Canada - US softwood lumber dispute occurred during this recessionary period in the US. Concurrent with the recession was a strengthening of the US currency relative to Canadian currency, which provided opportunities for Canadian softwood lumber producers to increase their share in the US despite a market in recession (Fig. 7; Fukuda 2001). US lumber producers, unhappy with the increased competition from a lower-priced Canadian product during a recessionary time, precipitated the first modern efforts to restrict Canadian 

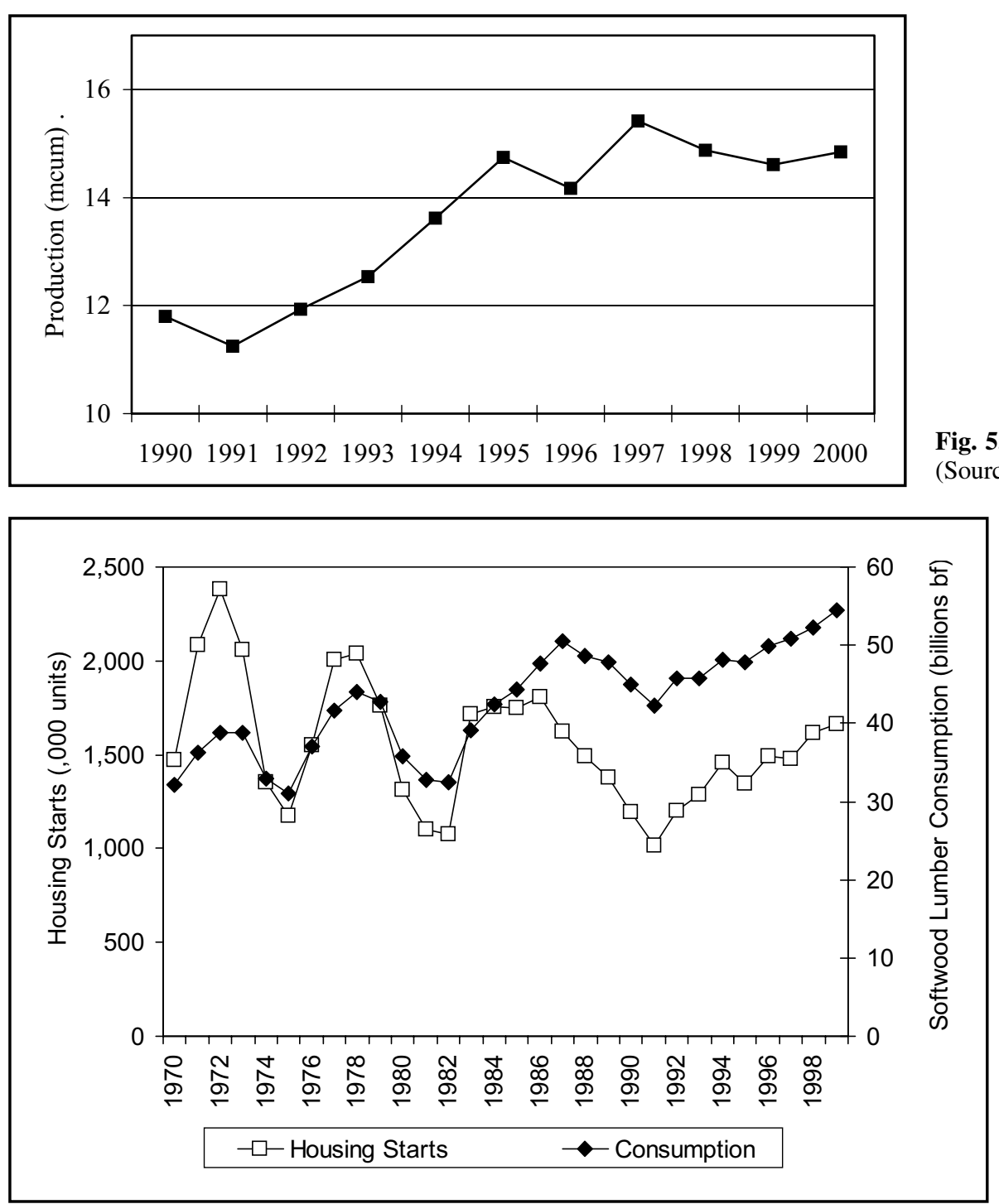

Fig. 5. Softwood Lumber Production in Sweden (Source: FAO 2001).
Fig. 6. US Softwood Lumber Consumption and Housing Starts (Source: Fukuda 2001). lumber exports to the US (Cashore 1997). The efforts to restrict imports of Canadian lumber are well documented in Eastin and Fukuda (2001). However, the continuation of efforts to restrict imports of softwood lumber from Canada into the US continued even during expansionary economic times. More information on this lengthy trade dispute is available from many of the referenced articles. However, one driver that maintained this pressure was the structural change in the US (and Canadian) wood products sector that contributed to continuing oversupply despite increasing housing starts.

During the 1980s, the production volume per sawmill increased significantly in both the US and Canada despite a decline in the total number of sawmills (for US data see Fig. 8). In fact, from 1982 to 1987 , the volume per US sawmill increased by $65 \%$. This investment in continuous process improvement during this period resulted in increasing supplies as well as better business performance for both US and Canadian operations (Cohen and Sinclair 1992).

The trend to upgrade existing sawmills and to establish new, more efficient sawmills started in the early 1970s as the sawmill sector reacted to a maturing market according to the previously mentioned Product Life Cycle theory (Random Lengths
1984, McCarthy et al. 1986). Lumber producers wanted to reduce production costs and increase recovery in mature and competitive markets and the modernization of many operations significantly increased output and productivity (Random Lengths 1986a, b). According to Random Lengths (1985a), the number of workers required to produce one million board feet of lumber in the Northwest declined from 4.5 in 1979 to 3.4 by 1984 . Ironically, this improved recovery contributed to the industry's overproduction problem by increasing output per man-hour, in addition to increasing the recovery of lumber from each log (Random Lengths 1985b). This increase in productivity contributed to a loss in employment and is consistent with the theories of Rowthorn and Ramaswamy (1998) and Grübler (1998).

Not only was the production of commodity lumber increasingly efficient due to process innovations, but new wood products were entering the market and eroding the market share of softwood lumber. Engineered Wood Products (EWPs), substitutes for softwood lumber in the North American market, were a rapidly growing segment of the wood products sector in the US during the 1990s (Fig. 9; Taylor 1999). The advantages of EWPs over conventional solid wood products continue to drive substitution even today, namely: 1) the superior uni- 


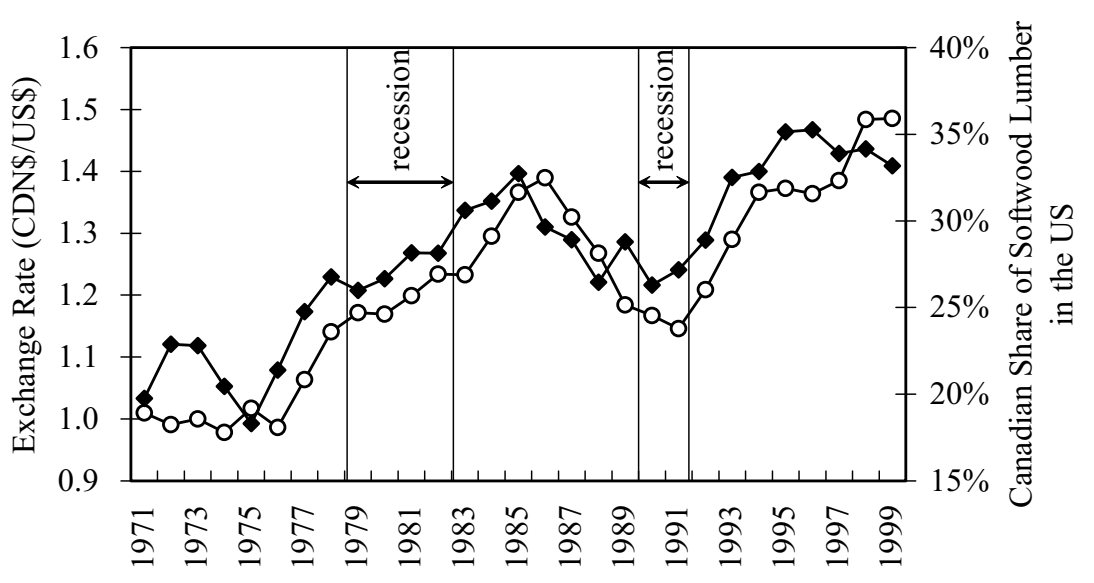

$\multimap-$ Exchange Rate $\multimap$ Canadian Share
Fig. 7. The Relationship between Exchange Rates and the Canadian Share of Softwood Lumber in the US (Source: Fukuda 2001).

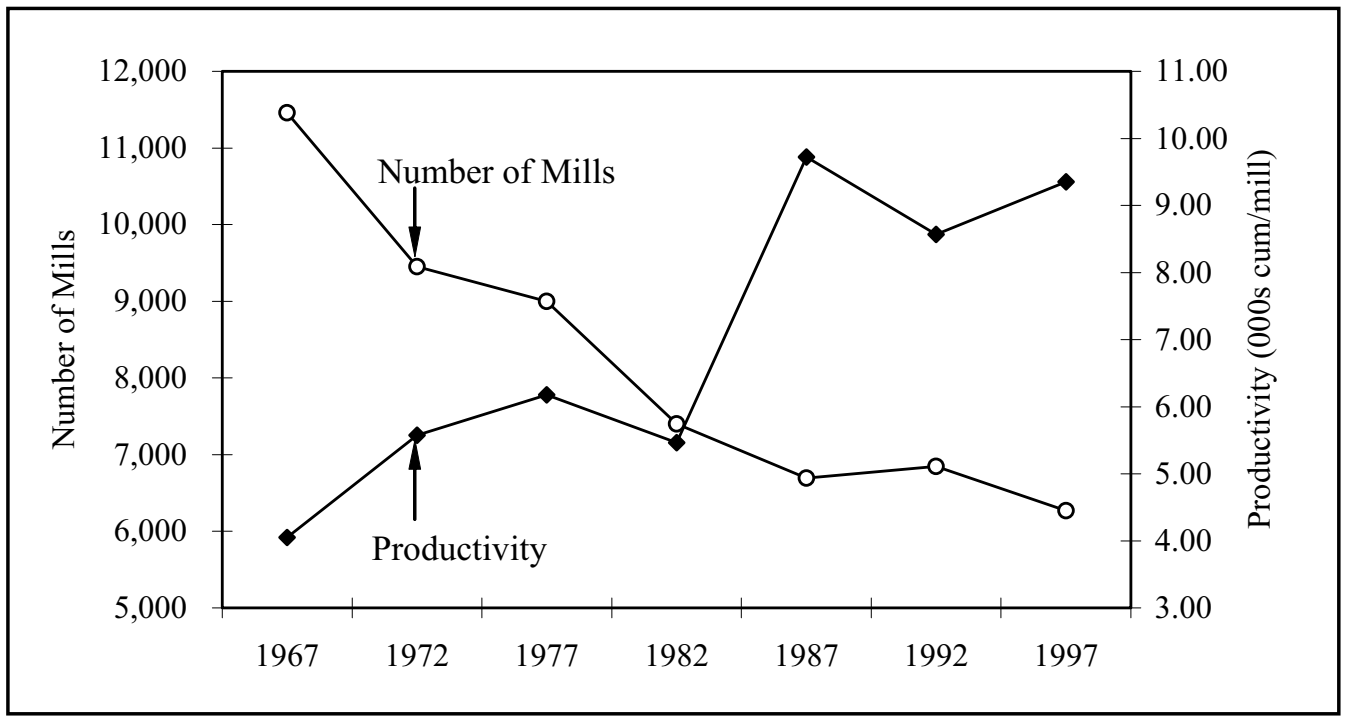

Fig. 8. Number of Sawmills and Planer Mills and Productivity in the US (Source: Howard 1999; USDOC 1984, 1995, 2000).

formity of physical strength, which enables enhanced design values; and 2) the final product yield from the tree is significantly improved compared to lumber recoveries, resulting in equal or improved performance from less (and lower quality) wood supplies (UN-ECE 2000). As a result, EWPs have rapidly captured market share. For example, I-beams have more than $40 \%$ market share of raised wood floors for new construction in the US, doubling its share from 20\% in 1995 (UN-ECE 2000).

In contrast, conventional wood products, such as softwood lumber, are meeting consumer resistance and market difficulties (Taylor 1999). There are several reasons that explain why lumber is losing appeal. One reason is the declining availability of knot-free, tight-grained old-growth timber, and the oversupply of smaller dimension, second-growth timber that has led to a public perception of decreasing quality because of its small diameter and abundance of juvenile wood (UN-ECE 2000). In addition, the focus by governments, ENGOs and producers of competing materials (e.g., steel) on forestry and forestry practices, coupled with an increasing public perception that wood is not an environmentally friendly material, has resulted in more stringent environmental regulations that serve to add costs to lumber production (UN-ECE 2000).

\section{The Framework}

At face value, the situations in the EU and the US seem dissimilar. However, a common logical progression in both situations leads towards the final implementation of NTMs. Factors leading to oversupply situations, such as recession, process innovation (leading to improved productivity), product innovation (leading to EWPs), increased domestic or regional production, and increased competition from imports all contribute to the implementation of restrictive trade measures, both tariffs and NTMs.

We have developed a framework (Fig. 10) which ties together these factors and illustrates the phases that contribute to oversupply and enhance the atmosphere for protectionism. Rectangles surrounded by a black line indicate the volume of demand for softwood lumber in each phase. The combination of domestic production (the shaded area in Fig. 10) and imported production (the white area) indicates the volume of total supply. Gaps between supply and demand determine prices, i.e., if supply exceeds demand, prices decline until supply is reduced and vice versa. Phase 1 (in Fig. 10) represents a normal or status quo state with a balance between overall supply (both from domestic and imported sources) and demand. 


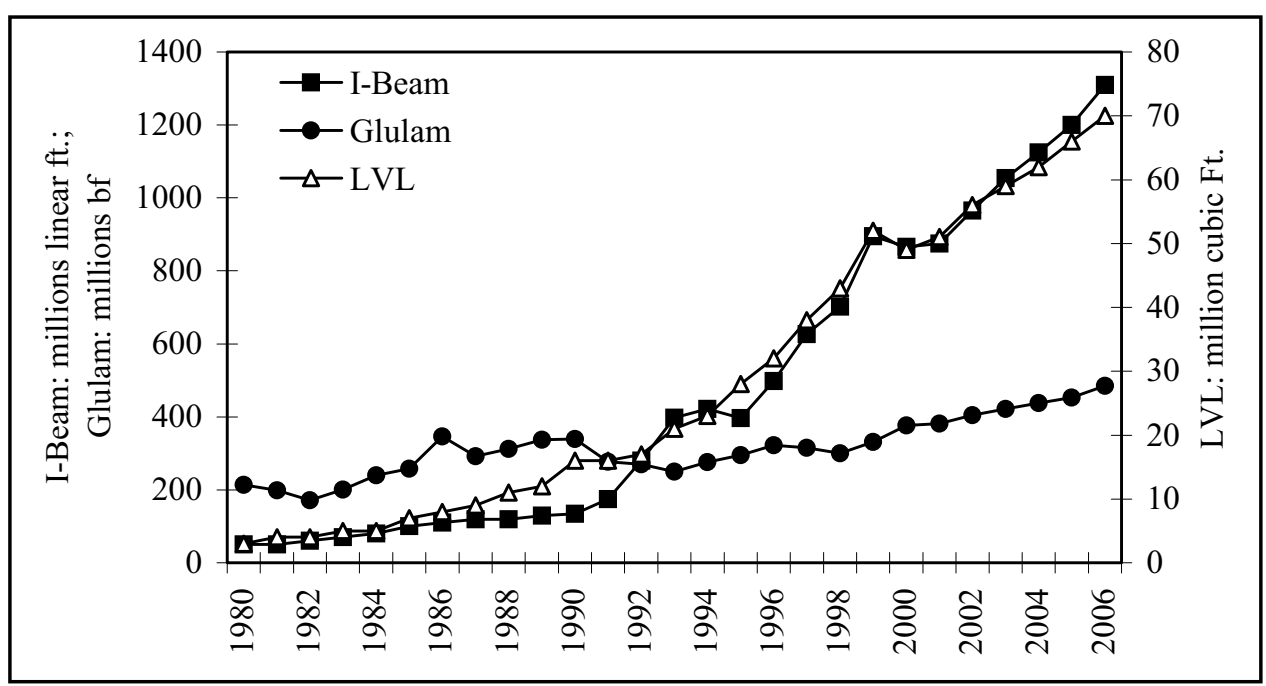

Fig. 9. Production of Engineered Wood Products (EWPs) in the US and Canada (Production values from 2001 to 2006 are estimates) (Source: Adair 2001).
In Phase 2, recession decreases demand, creating market oversupply, a downward pressure on prices and, ultimately, poorer financial performance by manufacturers. As domestic producers incur financial losses, they become increasingly impatient with the prevalence of imports in their domestic market over a short time horizon. This impatience leads to direct pressure to encourage the government to adjust the balance between domestic and imported supply and to ensure a reduction in imports. The argument is that this will lead to a more complete utilization of domestic capacity, increase employment, and contribute to a recovery from the recession.

As Drucker (2001) has indicated, there is often a great deal of emotion surrounding job losses and potential bankruptcies during recessionary times, which can trigger a public sentiment and a social environment that supports protectionism. US producers initiated the start of the current Canada-US softwood lumber dispute in the second year of a deep recession in 1982 after four years of declining lumber consumption (Fig. 6) and increasing Canadian market share (Fig. 7). Finland announced the discovery of the pinewood nematode in 1983, before the UK and Europe had recovered from the same global recession. Sweden, the largest European softwood lumber producer, had been rapidly losing market share to Canadian lumber producers in the largest European import market (the UK) during this recessionary period. The similarities between the situations in the EU and the US are obvious.

In addition to recessions that serve to decrease demand, increases in production due to technological adoption also contribute to oversupply situations. In fact, recession often instigates increased process innovation to improve productivity, reduce costs, and eventually increase profitability. This process innovation generally leads to more output from a mill, and total domestic supplies consequently increase (Phase 3 in Fig. 10). This phase was observed in the US and Sweden during the late 1980s and early 1990s. As a result of upgrading their facilities, productivity in these regions dramatically increased, resulting in increased output of softwood lumber per sawmill. With increased productivity, the number of sawmills decreased leaving the largest and most efficient sawmills to produce greater volumes of product in the face of decreased employment due to technological and labour efficiencies. Upgrades of these larger sawmills resulted in con- tinuously increasing production and a continuously decreasing cost of processing despite a decrease in the number of overall mills. Thus, industry structure changes and becomes more productive in reaction to recessions, which mitigates against many of the economic benefits seen in times of recovery. In other words, overcapacity puts downward pressure on the price increases that would normally occur during economic growth. The empirical impact of technology adoption for sawmills supports the concepts put forth by Rowthorn and Ramaswamy (1998) and Grübler (1998).

While improved process technologies in sawmilling serve to increase supply of lumber products, improved process technologies relating to new product innovation (Phase 4 in Fig. 10) contribute to a decrease in the overall demand for softwood lumber. The shift from high-quality old-growth natural timber to lower quality logs from plantations and second-growth stands promoted the adoption of new processing technologies. Product innovations contributed to the removal of defects from lumber produced from lower quality logs (e.g., fingerjoined lumber). It also enabled the use of low quality logs to produce EWPs by utilizing processing innovations such as flakers, dryers, and presses (the black area in Fig. 10). These products have superior or more uniform properties compared to conventional softwood lumber produced from lower quality logs and thus have a clear competitive advantage over lumber products. This resulted in EWPs substituting for softwood lumber, capturing its market share (Phase 4). Thus, product technology contributed to a decline in overall softwood lumber demand, while simultaneously, process technology resulted in increased production and market supply. Increasing supply concurrent with declining demand generally serves to exacerbate protectionist pressures.

The adoption of both process and product innovations (technology) resulted in supply and demand imbalances, even in good economic times. With increasing supply and declining demand, some producers (either domestic producers or exporters of lumber or EWPs) stand to lose market share to reestablish a balance between demand and supply. The general assumption of national governments is that if a sector needs to decrease in size, imported products need to be limited to save the domestic industry. This is particularly true if the market share for imports visibly increase at the expense of domestic production. 


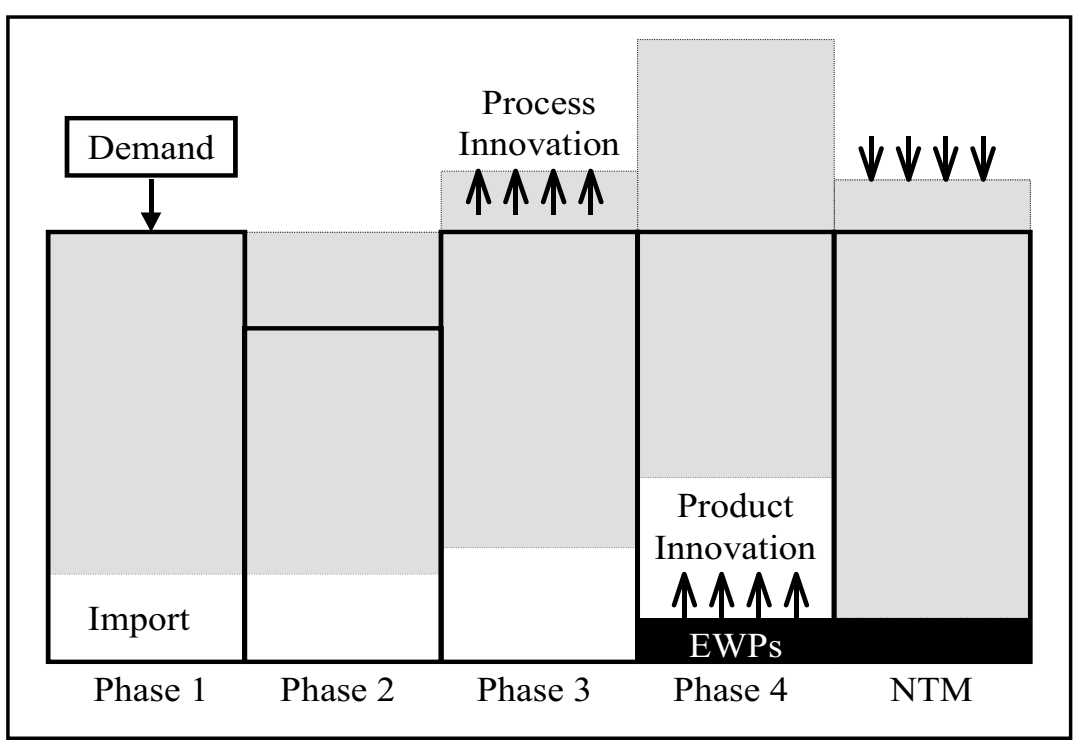

Fig. 10. Framework for the Implementation of NTMs.

\section{Limitations}

It should be noted that this framework excludes many exogenous variables, which can exacerbate protectionist measures. These include, but are not limited to, changes in relative exchange rates, investment intensities in both the exporting and importing countries, first mover benefits from productivity improvements and the intensity of political will leading to voluntary trade restraints (e.g., the SLA). However, these political and macro-economic aspects not only influence the use of NTMs, but all trade arrangements in general. The authors do recognize that there is a school of thought that considers that some of these exogenous variables, such as productivity gains and currency exchange rates, should be incorporated into this model. However, since these variables fluctuate by region over relatively short periods, they were omitted from this strategic framework.

\section{Discussion \\ Impact of framework}

Even though the World Trade Organization (WTO) allows for the implementation of trade restrictions when increasing imports seriously injure a domestic industry, this route was not used in either the European or the US measures. This is because the argument of imports injuring the domestic industry cannot stand scrutiny since the overall production of the domestic industry is often increasing at the same time as calls for protection are being made. Thus, trade restrictions under the international agreement cannot be used. The framework presented for each of these two cases clearly shows that injury to domestic industries was partially due to domestic technological adoption, increased production volumes, and job losses occurred because of increased productivity. In order to protect the domestic industry during these structural changes, NTMs, which are not clearly regulated for implementation under international trade agreements, were adopted in lieu of the more formal WTO trade restrictions to restrict imports and protect the domestic industry.

For softwood lumber, this framework is well supported. Canadian, European, and US producers adopted both process and product technologies to increase production. Canadian producers did so first, increased export volumes, and captured market share for softwood lumber in both markets. This contributed to lower prices and an atmosphere that enhanced protectionism. In Europe and the US, domestic producers lost market share in their own domestic markets, as competition became more intense. As prices declined, the domestic industry's antipathy for imports increased. From 1975 to 1985, the Canadian share of the US softwood lumber market continued to increase (Fig. 7). The US industry used this increasing share of Canadian softwood lumber as a key argument to win support for protectionist measures. During the latter half of the 1980s, the softwood lumber share held by European producers in Europe's largest market, the UK, had been decreasing while the Canadian share had been increasing. This also created an environment that supported the endorsement of trade restrictions.

Should current thinking about the decreasing importance of the manufacturing sector (in terms of employment and the concurrent shift towards the service sector) be correct and the proposed framework prove robust, then there are significant impacts for manufacturing industries that are heavily reliant on exports. This would hold true for much of the Canadian wood products industry, including not only the softwood lumber sector but also the pulp, paper, panel and value-added wood products sectors, all of which use timber resources from government-owned forests. The Canadian industry needs to understand the conditions under which trade restrictions are triggered and implemented in foreign markets in order to develop early warning signs and attempt to cope with this new wave of manufacturing protectionism. In an era of globalization, growing free trade and the WTO, it seems almost counterintuitive to predict increasing protectionism in manufactured goods such as wood products. However, international trade agreements cannot adequately address non-tariff trade measures. In addition, increasing pressure for environmental, labour and cultural protection in global free trade agreements creates ample opportunities for national self-interest to impede the implementation of free trade policies.

\section{Technology and trade protectionism}

The degree to which an industry is engaged in technology adoption is one clear indicator of a protectionist movement. In the US and European cases, one of the major drivers towards protectionism was domestic oversupply caused by the adop- 
tion of new process and product technologies. While EWPs captured share from softwood lumber, the production of softwood lumber increased despite a decline in the number of sawmills. Under these conditions, oversupply in both the US and Europe was caused not only by increasing imports but also by increasing domestic production. With overproduction of domestic softwood lumber and an increasing use of EWPs, it is rational that the domestic industries pressured governments to create additional space in the domestic market to sell their increased production and new products. This indicates that it may be prudent for exporting countries to monitor the adoption of technologies and changes in productivity of manufacturers in their target markets to develop an "early warning," not only of an imminent protectionist measure, but of their likelihood of success.

Japan is the second largest importer of Canadian lumber 4 Therefore, it is important to monitor Japan's efforts to protect its domestic sawmill sector through protection from imported wood products. Japan has been exploring the implementation of a safeguard action according to WTO principles in response to the increasing share of imported wood products to provide time for domestic mills to become competitive. Historically, Japan experienced oversupply caused by the creation of a large number of small sawmill operations after the Second World War. Although the Japanese government promoted the creation of large sawmills and a decrease in the total number of sawmills during the 1960s, it was a different type of movement from the one in both in the US and Sweden in the 1980s. Japan has not experienced the same level of process innovation as the US and the EU, and sawmill productivity is far lower than that in the US and the EU (Sato 2000, Fujikake 2002). However, should Japanese sawmills adopt new technologies and increase their efficiency and productivity, NTMs to protect the rebirth of their sawmill sector would follow according to the framework in Fig. 10. The technology status of sawmills in Japan should continue to be monitored to determine if, or when, the conditions would be suitable for the successful implementation of NTMs.

\section{Canada and the new protectionism}

For a major wood products-exporting country such as Cana$\mathrm{da}$, it is essential that an early warning system be developed to identify emerging areas of protectionism. The reactive approach is to wait until the domestic industry has organized and fight a defensive and retaliatory campaign to prevent the imposition of protectionist measures. The proactive approach would be to monitor the "precursors" to successful protectionist action and work to mitigate against these precursors prior to the protectionist action taking place.

There are likely two factors to monitor in an export market. The first is increasing domestic production due to technology adoption concurrent with declining employment. The second is an imbalance in supply and demand due either to recession (from declining demand) or oversupply (from production increasing at a more rapid rate than demand). If these two fac-

\footnotetext{
${ }^{4}$ In 1993 over $22 \%$ of Canadian lumber exports (by value) were shipped to Japan. This declined to less than $13 \%$ in 2001, as market share in Japan was lost to European producers and increased shipments to the US absorbed these declining volumes (data obtained through Strategis - Industry Canada from Statistics Canada). In 2001, Canada supplied $38 \%$ of all Japanese imports and supplied over 15\% of all Japanese lumber requirements (data obtained from Japan Wood Products and Information and Research Center from Japan Ministry of Finance).
}

tors occur in key export markets then efforts for protection from Canadian exports will likely increase and have a higher probability of success.

What can Canada do to circumvent the progression to increased protectionism? Early identification of the two precursory factors mentioned above can lead to proactive activities on both economic and political fronts. These activities should be based on current economic and political realities. Cases against countries imposing NTMs must stress the benefits to the importing country of Canadian wood products imports. Accurate records of remanufacturing jobs, reduced housing costs and supply chain partnerships can provide useful information for both lobbying efforts and pubic relations, to name a few examples. Many of the current initiatives related to promotion, advertising and linkages with US users of wood products could have been initiated prior to the current trade restrictions rather than in reaction to them.

Co-operative efforts between importing and domestic producers to "grow the market" and to increase overall wood use (similar to the current efforts of the newly formed Wood Promotion Network) could help to re-establish supply and demand balances without having to reduce imported supplies. Moreover, these sorts of long-term efforts can provide more positive and synergistic working relationships between producers in both importing and exporting regions. The market in North America could be grown by increasing the use of wood in nontraditional market segments like non-residential construction (e.g., offices, schools, stores, etc.), architectural appearance products (e.g., flooring, wainscoting, etc.), or as an industrial input for the manufacture of furniture, windows and other finished products. In addition, the generic promotion of wood as an environmentally suitable renewable material can help to increase demand. However, these efforts need to be initiated prior to the development of strong protectionist efforts or they may be seen as reactive, defensive, and ineffectual.

While some sectors can shift manufacturing facilities to the importing region in response to NTMs (e.g., the automotive industry), the nature of the wood products sector is such that manufacturing optimally takes places close to sources of fibre supply. Thus, one of the most effective means of reducing the threat of NTMs is to forge strong partnerships with manufacturers of finished products within importing countries. If domestic jobs in the importing markets are reliant on imported products, then NTMs could be seen to trigger increased job losses. Thus, the development of strong supply chain relationships with manufacturers in importing regions using imported Canadian manufactured wood products creates a convincing argument to retain unrestricted trade in importing regions. This type of relationship should be combined with use of the previously mentioned early warning systems so that actions (such as the recent advertisements in the US supported by major importing retailers and builders aimed at raising the profile of this issue among the US public) can be timed effectively to avoid the imposition of NTMs.

\section{Conclusion}

The growth of NTMs to restrict free trade in Canadian softwood lumber is an indication of increasing protectionism for all manufactured goods. This trend will continue as technology and product innovations continuously improve manufacturing efficiency, productivity, and production and as more and more employ- 
ment shifts from the manufacturing sector to the service sector. Economic downturns combined with increased domestic production will trigger this increased protectionism, likely taking on the form of NTMs since current bilateral and global trade agreements restrict the use of direct tariff restrictions.

The main advantage the framework presented in this paper is the early detection of impending trade restrictions as a means of providing information for better operational planning. Understanding the global context of the recent NTMs reducing access to global markets for Canadian softwood lumber can help frame strategies and policies to mitigate against some of the negative impacts of increasing restrictive trade in wood products. While more work is needed to validate and expand the framework presented in this paper, it does provide a useful starting point for discussions on how to monitor and identify future trade frictions and how best to prepare to prevent their implementation or, at the very least, minimize their impact.

\section{References}

Adair, C. 2001. Regional production \& market outlook. Structural panels \& engineered wood products 2001-2006. APA Economics Report E 67. March 2001.

Apsey, T. and J.C. Thomas. 1997. Lessons of the Softwood Lumber Dispute: Politics. Cited in Cashore 1997. Flights of the phoenix: Explaining the durability of the Canada - U.S. softwood lumber dispute. Canadian-American Public Policy No.32. Canadian-American Center, University of Maine, Orono, Main. 10 p.

Bourke, I.J. and J. Leitch. 1998. Trade restrictions and their impact on international trade in forest products. http://www.fao.org/forestry/ fop/foph/bkleich/B98-1.stm.

Cashore, B. 1997. Flights of the phoenix: Explaining the durability of the Canada-U.S. softwood lumber dispute. Canadian-American Public Policy No.32. Canadian-American Center, University of Maine, Orono, Main.

CIBC World Markets. 2002. Equity Research - Spotlight on the Paper and Wood Stocks, May 6 - May 10, 2002. p. 7. Published by the Canadian Imperial Bank of Commerce, Toronto, ON.

Cohen, D.H. and S.A. Sinclair. 1992. The Strategic Management Paradigm and the Wood Building Products Industry: A Model of Strategies and Firm Profitability. Forest Science 38(4): 786-805.

Doyle, R. 2002. Deindustrialization: Why Manufacturing Continues to Decline. Scientific American 286(5): 30.

Drucker, P. 2001. The Manufacturing Paradox. economist.com. November 1, 2001. Downloaded from http://www.economist.com/ surveys/PrinterFriendly.cfm?Story_ID=770861.

Eastin. I. and J. Fukuda. 2001. The Impact of Regulatory Change on the International Competitiveness of the Canadian Softwood Lumber Industry. For. Chron. 77(2): 315-323.

The Economist. 2002a. Dangerous Activities. May 9, 2002 edition. Downloaded from the Web site. The Economist, London.

The Economist. 2002b. Will These Modest Proposals Provoke Mayhem Down on the Farm? July 13, 2002 edition. Downloaded from the Web site. The Economist, London.

Food and Agricultural Organization (FAO). 2001. FAOSTAT Agriculture data. (revised in November 2001). Downloaded from http://apps.fao.org/page/collections?subset=agriculture (14 February 2002).

Fujikake, I. 2002. The Sawmill Industry, Chapter 10 In Y. Iwai (ed.). Forestry and the Forest Industry in Japan. pp. 179-197. UBC Press, Vancouver, BC.

Fukuda. J. 2001. A Study of the Effects of the Canada-U.S. Softwood Lumber Agreement. CINTRAFOR Working Paper 80. University of Washington, Seattle, WA.

Grübler, A. 1998. Technology and Global Change Cambridge University Press, Cambridge. 407 p.
Hicks, C.M. 2001. Exotic Pests and International Trade. Exotic Forest Pests Online Symposium. April 16-29, 2001. Downloaded from http://exoticpests.apsnet.org/Papers/hicks.htm (February 20, 2002). Hill, C.T. and J.M. Utterback. 1979. Technological Innovation for a Dynamic Economy. Pergamon Press, Elmsford, New York. 337 p. Howard, J.L. 1999. U.S. Timber Production, Trade, Consumption, and Price Statistics 1965-1997. USDA, Forest Service, Forest Products Laboratory, General Technical Report FPL-GTR-116.

McCarthy, E.J, S.J. Shapiro and W.D. Perreault, Jr., 1986. Basic Marketing, Fourth Canadian Edition. Irwin Publishing, IL. 869 p.

McKenna, B. 2001. U.S. Mills Fear Attack by Canadian "Wall of Wood." The Globe and Mail, Vancouver, B.C., 21 March.

New Zealand Forest Research Institute. 1999. Study of NonTariff Measures in the Forest Products Sector. Report of Asia Pacific Economic Cooperation. Committee on Trade and Investment. Downloaded from http://www.forestresearch.co.nz/topic. asp?docid $=1067 \&$ contenttype $=$ general $\&$ topic $=$ Strategic $\% 20$ Market\%20Intelligence \& title $=$ Trade\%20Access.

Nylinder, M., M. Warensjö, C. Lundgren, A. Jäppinen and H. Fryk. 1997. The Swedish Sawmilling Industry. Downloaded from http://www. sh.slu.se/svensk/Saginv95/saginv/english/ (22 February 2002).

Random Lengths. 1984. Through a Knothole. Random Lengths Publications Inc., Eugene, OR. (16 March).

Random Lengths. 1985a. Through a Knothole. Random Lengths Publications Inc., Eugene, OR. (8 February).

Random Lengths. 1985b. Through a Knothole. Random Lengths Publications Inc., Eugene, OR. (15 November).

Random Lengths. 1986a. Through a Knothole. Random Lengths Publications Inc., Eugene, OR. (10 January).

Random Lengths. 1986b. Through a Knothole. Random Lengths Publications Inc. Eugene, OR. (27 June).

Random Lengths. 1993. Exemptions to EC Ban Sought. Random Lengths Publications Inc., Eugene, OR. (10 November).

Rowthorn, R. and R. Ramaswamy. 1998. Growth, Trade and Deindustrialization. A Working Paper of the International Monetary Fund, April 1998 WP/98/60. International Monetary Fund, Washington, DC.

Sato, J. 2000. Japan sawmill industry; Getting larger for domestic timber. Japan Lumber Journal. September 30, 2000.

Skogsindustrierna. 2001. The Sweden Forest Industries 2000: Facts and figures. Downloaded from http://www.forestindustries.se/eng/filer/faktafoldern_eng_01.pdf (February 22, 2002).

Swedish Institute. 2001. Forestry and the Forest Products Industry. Swedish Industry, Fact Sheet 129A, November, 2001. Downloaded from http://www.si.se/docs/infosweden/engelska/fs129a.pdf (March 7, 2002).

Taylor. R.E. 1999. Wood Markets. 2000 Edition: The Solid Wood Products Outlook 2000 to 2004. International Wood Markets Research Inc., Vancouver. 385 p.

TED - The Trade and Environmental Database. 1993. Nematode Pine Ban by EC. Downloaded from http://www.american.edu/TED/nematode.htm (13 February 2002).

United Nations - Economic Commission for Europe (UN-ECE), Timber committee. 2000. Forest Products Annual Market Review, 1999-2000. Timber Bulletin, Vol. LIII, ECE/TIM/BULL/53/3. Downloaded from http://www.unece.org/trade/timber/docs/rev00/rev00.htm.

United States, Department of Commerce (USDOC). 1984. Statistical Abstract of the United States.

United States, Department of Commerce (USDOC). 1995. Statistical Abstract of the United States.

United States, Department of Commerce (USDOC). 2000. Statistical Abstract of the United States. 